\title{
Al-Qoran Views of Tobacco Smoke Exposure on Pregnant Women
}

\author{
Tamrin Talebe' ${ }^{1}$ Haerani Harun ${ }^{2}$, Anwar Daud ${ }^{3}$, Veni Hadju ${ }^{4}$, \\ Ridwan Amiruddin ${ }^{5}$, Rosmala Nur ${ }^{6}$, Anwar Mallongi ${ }^{3}$ \\ ${ }^{1}$ Faculty of Ushuluddin, Islamic Institute of Datokarama, Indonesia, ${ }^{2}$ Student of Doctoral Program, Faculty of \\ Public Health Hasanuddin University, Makassar, Indonesia, ${ }^{3}$ Professor, Department of Environmental Health \\ Faculty of Public Health Hasanuddin University, Makassar, Indonesia, ${ }^{4}$ Professor, Department of Nutritional \\ Sciences Faculty of Public Health Hasanuddin University, Makassar, Indonesia, ${ }^{5}$ Professor, Department of \\ Epidemiology, Faculty of Public Health Hasanuddin University, Makassar, Indonesia, ${ }^{6}$ Senior Lecturer of \\ Department of Public Health, Faculty of Public Health, Tadulako University, Palu, Indonesia
}

\begin{abstract}
Smoking has become a serious problem for all nations of the world. The threat of the adverse effects of smoking on the health of pregnant women has shown an adverse effect. Pregnant women affected by tobacco smoking may give birth to low birth weight babies (LBW), preterm birth and stillbirth. The religion of a person can play a role in changing the attitude of a society towards bad actions. The teachings of Islam through verses of the Koran teaches to create environmental conditions that are appropriate for a pregnant woman. Achieve safety in the fabric of human life through prevention of negative behaviors that lead. Realizing a healthy family environment situation. Creating a harmonious family full of happiness and meeting physical and spiritual needs.
\end{abstract}

Keyword: Tobacco smoke, pregnancy, Qoran, pregnant outcome.

\section{Introduction}

Smoking has become a global public health problem. Since the beginning of the 20th century tobacco smoke consumption has increased throughout the world. Around 1.1 billion people aged 15 years and over are smokers. Smoking not only has an effect on active smokers but also has the potential to be a health disorder for those around them exposed to cigarette smoke. ${ }^{1,2}$ According to the World Health Organization (WHO) in the Global Tobacco Epidemic report, smoking is a global health problem that causes death in 5 million people every

\section{Corresponding Author:}

\section{Haerani Harun}

Student of Doctoral Program, Faculty of Public Health Hasanuddin University, Makassar, Indonesia

Mobile No.: +6285242010535

e-mail: haeraniharun.unhas@gmail.com year. ${ }^{3,4}$ The adverse effects of smoking on pregnancy are widely known, the prevalence of smoking in women has decreased in high-income countries in 50 years, but the prevalence has increased in middle and low income countries. $^{5,6}$

Passive smoking is estimated to cause death in $1.0 \%$ of the world's population, 603,000 deaths in children and adults and the number is increasing every year. Secondary smokers are people who are exposed to cigarette smoke from the environment (environmental tobacco smoke, ETS). ${ }^{7}$ Exposure to secondary tobacco smoke during pregnancy is often associated with various health problems for mothers and the babies. Various studies have shown pregnant women who are exposed to cigarette smoke increase the risk of babies born. Pregnant women exposed to tobacco smoke have the possibility to give birth to low birth weight babies (LBW), give birth pretermly and stillbirth. ${ }^{8-12}$ Exposure to tobacco smoke during pregnancy also increases the risk of babies born with Respiratory distress syndrome 
(RDS), being treated in intensive neonatal care and early neonatal complications. ${ }^{13}$

Religion also pays serious attention to the effects caused by smoking. The religious teachings adopted by a pregnant woman also have a strong influence on her pregnancy. That research shows $47 \%$ rate believes that spiritual is very influential on a pregnant woman's pregnancy. This indicates that religious teachings are the most important part and basic needs in pregnancy. Islam based on the Qur'an Surah Maryam verse 16 contains instructions to Maryam who will enter the labor process. Mary is a symbol of the role of a woman who is pregnant must do something positive for herself. Self-protection Maryam who is pregnant is part of the teaching of protection against external interference that can endanger her and prepare herself carefully in accepting her responsibilities as a mother.

Effect of Smoking on Health: Cigarettes contain a variety of harmful substances including nicotine, cotinin, cadmium carbon dioxide, asbestos, arsenic, benzene and radon gas. ${ }^{14,15}$ Nicotine is a water-soluble bioactive alkaloid with parasympathomimetic effects and addictive substances. Nicotine is obtained from the leaves and stems of the tobacco plant Nicotianatabacum which originates from North and South America. Tobacco was later introduced to Europe for pleasure effects and some medical benefits. ${ }^{16}$

Exposure to secondhand smoke significantly increases the risk of lung cancer in adult smokers and increases the risk of asthma, lower respiratory tract infections and decreases lung function in children. Smoking increases the risk of apnea during sleep and exacerbation of asthma in the adult population and pregnant women. Active and passive smokers increase the risk of tuberculosis infection. ${ }^{17}$

Tobacco Smoke Exposure on Pregnant Women: Pregnant women who are exposed to cigarette smoke from the environment or passive smokers have the potential to be a health problem in the community, about $22-30 \%$ of non-smokers women are exposed to cigarette smoke from the environment. ${ }^{18}$ Data from other studies show that $37 \%$ of pregnant women are passive smokers. ${ }^{19}$ Nicotine is a major component of smoking, its effects on pregnancy have been found in several studies. ${ }^{1}$

Nicotine and carbon monoxide can cause various disorders for the fetus, ranging from disorders of the placenta to disorders of the fetal circulation. ${ }^{9,14,20,21}$
Smoking during pregnancy is not only dangerous for the mother but also the fetus in her womb. ${ }^{22}$ Smoking in pregnancy can cause preterm birth, miscarriage, ectopic pregnancy, antepartum bleeding, placenta previa, small babies for gestational age, small baby head circumference, increased risk of low birth weight babies (LBW) and congenital anomalies. The effects of smoking on pregnancy that cause adverse effects on birth are well known, but the effects of pregnant women as passive smokers have not been so widely studied and understood. ${ }^{18}$

Pregnant women are an active risk group for cigarette smoke both actively and passively. ETS smoke is a complex mixture consisting of most of the smoke emitted from the smoker's body plus the smoke produced by burning cigarettes and the surrounding air. ${ }^{7}$ Exposure to ETS in pregnant women causes increased levels of $\mathrm{CO}$, nicotine and cotinin in maternal serum or urine, in infants and in amniotic fluid. The influence of ETS on pregnant women can occur from the first semester to the third semester. Pregnant women are usually exposed to ETS in various places with different duration of time. Places that have the potential to become ETS exposure locations include at home, at work and the outside environment. ${ }^{10}$

The physical environment has an important role in determining the weight of babies born and their health in the future. Research in Jordan shows that ETS exposure in non-smoking pregnant women causes an increased incidence of low birth weight babies (LBW). Increased ETS exposure increases the risk of LBW infants. All ETS exposure in the home, office and outside environment has the potential to reduce the weight of babies born. It was also found that second and third semester exposures were the most vulnerable time of exposure causing LBW. LBW infants tend to be more at risk for neurological problems including cerebral palsy, seizures, severe mental retardation, respiratory diseases and other morbidity. ${ }^{10}$ Research shows that smoking during pregnancy increases the risk of preterm birth by $25 \%{ }^{6}$

ETS exposure also specifically has an influence on preterm birth. ${ }^{23,24}$ Smoking is known to cause an increased risk of spontaneous and elective preterm birth, but has a stronger relationship with spontaneous preterm birth. Passive smoking in pregnancy also has a risk of preterm birth both spontaneous and elective. ${ }^{20}$ Elective preterm delivery is likely to be related to cigarette- 
related obstetric complications such as placenta previa, placental abruption and impaired fetal growth. Research shows that smoking during pregnancy increases the risk of preterm birth by $25 \% .{ }^{6}$ ETS exposure also specifically has an influence on preterm birth. ${ }^{23,24}$

Smoking can also increase the risk of preterm rupture of membranes through several mechanisms, namely: (1) smoking decreases immunity and becomes a predisposing factor for infection, (2) smoking decreases copper levels and ascorbic acid in the blood. The micronutrients can cause a decrease in the elasticity of the membranes and increase the risk of rupture of the membranes. Both of these mechanisms have the potential to cause preterm birth. ${ }^{6}$

The Qoran Views Of Smoking: Based on the negative effects of smoking in the order of human life, the Qoran forbids all forms of actions that lead to harm and adverse effects of a human action or policy (QS. Albaqarah; 2: 195). This proposition becomes the basis for the prohibition of all human attitudes and actions that can threaten his survival. The teachings of the Qoran require human life in good condition. Every part of his life must avoid evil and harm and survivalthreaten. In Surah al-Nahl verse 97 explains that everyone who does a joint activity, then positive things must be a priority in the environment:

Whoever works righteousness, man or woman, and has Faith, verily, to him will We give a new Life, a life that is good and pure and We will bestow on such their reward according to the best of their actions.

The teachings in this verse are aimed at all people without having to distinguish roles in the sex in doing good. The responsibility of doing good is an obligation that must be done for those who believe if they want to perfect their faith. Salih is the opposite of alfasad (bad or error). Positive deeds, salih must be a priority scale for humans. Because salih is a real thing in human life, it should be the spearhead in the order of life..$^{25}$

The Qur'an requires human life in the circumstance of thayyibah. Hayatanthayyibah is a picture of a life that deserves goodness. The state of life that meets the healthy requirements and meets both the material, psychological and spiritual needs so as to create a good and comfortable life without being overwhelmed by anxiety and boredom. Good and comfortable are not based on the availability of material, so the material will not affect/damage the desire for religious obligations. ${ }^{26}$
The Quran And Tobacco Smoke Exposure On Pregnant Mother: The goal as a family is to be achieved is the realization of the sakinah, mawaddahwarahmah as revealed in surah Arrum verse 21: that God has planted the potential in each family to live happily, meet each other's needs and maintain harmony with one another.

And among His Signs is this, that He created for you mates from among yourselves, that ye may dwell in tranquillity with them, and He has put love and mercy between your (hearts): verily in that are Signs for those who reflect.

Life is full of peace with the pronunciation of Yaskunu in the above verse using the verb expression, giving a signal that the family must keep trying to find and maintain peace in family life so that all the hearts of family members are always calm. The word mawaddah in the context of this verse means love and love for all life activities and gives birth to a sense of comfort. Family members must have a good relationship, a sense of caring gives birth to a safe and loving situation, mercy. ${ }^{27}$

A pregnant woman with the responsibility of maintaining the health of the fetus (hifz al-nasl) it contains is very dependent on a healthy environment. A healthy environment will play an important role in creating a comfortable situation and giving birth to highquality offspring and a person is not justified in making efforts to eliminate the comfort of others, including in the family. Conversely, in an environment that threatens the lives of women and fetuses due to smoking, which is conceived, stated:"If a man kills a believer intentionally, his recompense is Hell, to abide therein (For ever): And the wrath and the curse of Allah are upon him, and a dreadful penalty is prepared for him."(Al-Nisa [4]:93), "And those who annoy believing men and women undeservedly, bear (on themselves) a calumny and a glaring sin." (Al-Ahzab [33]: 58) .

\section{Conclusion}

Various studies showed that smoking has a negative effect on the mother and the baby. Stillbirth, preterm birth and malnutrition in infants are the effects of tobacco smoke on pregnant women. The adverse effects of smoking can threaten human life, the Qoran prohibits all forms of actions that lead to harm and adverse effects of an action or human policy (Surah Al-Baqarah; 2: 195). This proposition becomes the basis for the prohibition of all human attitudes and actions that can threaten his survival. The teachings of the Koran require 
human life in good condition and benefits. Whatever is a part of his life must avoid evil and harm and threaten human survival. In surah al-Nahl verse 97 explains that everyone who does joint activities,

Ethical Clearance: Taken from University ethical committee

Source of Funding: Self

Conflict of Interest: Nill

\section{References}

1. Andriani, H. \& Kuo, H.-W. Adverse effects of parental smoking during pregnancy in urban and rural areas.BMC Pregnancy Childbirth 2014; 14, 414.

2. Braun, M., Koger, F., Klingelhöfer, D., Müller, R. \& Groneberg, D. Particulate Matter Emissions of Four Different Cigarette Types of One Popular Brand: Influence of Tobacco Strength and Additives. Int. J. Environ. Res. Public. Health 2019; 16, 263

3. World Health Organization. WHO report on the global tobacco epidemic, 2017: monitoring tobacco use and prevention policies.(World Health Organization,).

4. Demirhan, O. Results of Smoking in Pregnancy: The Genotoxic Effect of Nicotine or why Cigarette should not be Smoked in Pregnancy? 4. 2017.

5. Klein, J., Blanchette, P. \& Koren, G. Assessing nicotine metabolism in pregnancy - a novel approach using hair analysis. Forensic Sci. Int. 2004; 145, 191-194.

6. Ion, R. \& Bernal, A. L. Smoking and Preterm Birth. Reprod. Sci 2015; .22, 918-926

7. Torres, S., Merino, C., Paton, B., Correig, X. \& Ramírez, N. Biomarkers of Exposure to Secondhand and Thirdhand Tobacco Smoke: Recent Advances and Future Perspectives. Int. J. Environ. Res. Public. Health 2018; 15, 2693.

8. Alemán, A. et al. Brief Counseling on Secondhand Smoke Exposure in Pregnant Women in Argentina and Uruguay. Int. J. Environ. Res. Public. Health 2016; 14, 28.

9. Khader, Y. S., Al-Akour, N., AlZubi, I. M. \& Lataifeh, I. The Association Between Second Hand Smoke and Low Birth Weight and Preterm Delivery. Matern. Child Health J. 2011; 15, 453459
10. Abu-Baker, N., Haddad, L. \& Savage, C. The Influence of Secondhand Smoke Exposure on Birth Outcomes in Jordan. Int. J. Environ. Res. Public. Health 2010; 7, 616-634.

11. Luo, Y.-J. et al. Interaction between Maternal Passive Smoking during Pregnancy and CYP1A1 and GSTs Polymorphisms on Spontaneous Preterm Delivery. PLOS ONE7, e49155 (13 Nov 12).

12. Ward, C., Lewis, S. \& Coleman, T. Prevalence of maternal smoking and environmental tobacco smoke exposure during pregnancy and impact on birth weight: retrospective study using Millennium Cohort. BMC Public Health 2007; 7, 81.

13. Ashford, K. B. et al. The Effects of Prenatal Secondhand Smoke Exposure on Preterm Birth and Neonatal Outcomes. J. Obstet. Gynecol. Neonatal Nurs. 2010; 39, 525-535.

14. Goel, P., Radotra, A., Singh, I., Aggarwal, A. \& Dua, D. Effects of passive smoking on outcome in pregnancy. J. Postgrad. Med. 2004; 50, 12

15. Sánchez-Rodríguez, J. E. et al. Anti-smoking legislation and its effects on urinary cotinine and cadmium levels. Environ. Res. 2015; 136, 227-233.

16. Alkam, T. \& Nabeshima, T. Molecular mechanisms for nicotine intoxication. Neurochem. Int. 2019; $125,117-126$

17. Jayes, L. et al. SmokeHaz: Systematic Reviews and Meta-analyses of the Effects of Smoking on Respiratory Health. Chest 2016; 150, 164-179

18. Salmasi, G., Grady, R., Jones, J. \& McDonald, S. D. Environmental tobacco smoke exposure and perinatal outcomes: a systematic review and metaanalyses. Acta Obstet. Gynecol. Scand.2010; 89, 423-441

19. Pineles, B. L., Park, E. \& Samet, J. M. Systematic Review and Meta-Analysis of Miscarriage and Maternal Exposure to Tobacco Smoke During Pregnancy. Am. J. Epidemiol. 2014; 179, 807-823

20. Qiu, J. et al. Passive Smoking and Preterm Birth in Urban China. Am. J. Epidemiol. 2014; 180, 94-102

21. Wu, F.-Y. et al. Associations among genetic susceptibility, DNA damage, and pregnancy outcomes of expectant mothers exposed to environmental tobacco smoke. Sci. Total Environ. 2017; 386, 124-133

22. Setiati, S. \& Laksmi, P. W. Peran Internis dalam tata laksana penyakit-penyakit pada kehamilan. 
PIPInterma, 2019.

23. Hayes, C. et al. Patterns of Smoking Behaviour in Low-Income Pregnant Women: A Cohort Study of Differential Effects on Infant Birth Weight. Int. J. Environ. Res. Public. Health 2016; 13, 1060.

24. Elkin, E. R. \& O’Neill, M. S. Trends in Environmental Tobacco Smoke (ETS) Exposure and Preterm Birth: Use of Smoking Bans and Direct ETS Exposure Assessments in Study Designs. Chem. Res. Toxicol.2017; 30, 1376-1383 .

25. Alragib Alashfahani. al-Mufradat fi Garib Alquran. 2, (2017).

26. Wahbah Az-Zuhaili. Tafsir al-Munir.inTafsir AlMunir7, (2005).
27. Muhammad Thahir bin 'Asyur. Tafsir al-Tahrir wa al-Tanwir. inTunis; $1997:$ 8, 73.

28. Russeng, S.S., Saleh, L.M., Virani, D., Latief, A.W.L., Mallongi, A. The investigation of the lactic acid change among employee of national electrical power plan.Indian Journal of Public Health Research and Development 2018; Volume 9, Issue 1, Pages 361-365.

29. Rosmala Nur, Sitilka Fitrasyah, Anwar Mallongi, Women's Reactions and Health Disorders Caused by Abuse During the Pregnancy-Postpartum Period. Medico-legal Update, January-March 2020, Vol. 20, No. 1 